\title{
Radyo Çocuk Kulübü ve Müzik Yayınları Üzerine Bir Araștırma
}

\section{A Research on Radio Kids Club and Music Broadcasts}

\section{Türker Erol}

Dr. Öğr. Üyesi, Sivas Cumhuriyet Üniversitesi Eğitim Fakültesi Güzel Sanatlar Eğitimi Bölümü Müzik Eğitimi Anabilim Dalı email: trkero176@gmail.com (DORCID ID: https://orcid.org/0000-0001-9746-8934

iThenticate' Bu makale bilimsel etik ve kurallara uygun hazırlanmış ve intihal incelemesinden geçirilmiştir.

Atıf (APA 6)/To cite this article

Erol, T. (2020). Radyo çocuk kulübü ve müzik yayınları üzerine bir araştırma. Atatürk Üniversitesi Güzel Sanatlar Enstitüsü Dergisi, 26(Müzik Özel Say1s1), 338-352. doi: https://doi.org/10.35247/ataunigsed.684023

Makale Gönderim Tarihi/Received: 10/12/2019

Makale Kabul Tarihi/Accepted: 19/02/2020

Makale Yayın Tarihi/Published: 25/03/2020

Research Article / Araștırma Makalesi

Öz

Radyo Çocuk Kulübü, sadece bir eğlence programı değil, dönemin çocuk terbiyesini radyonun nasıl ele aldığını gösteren, önemli bir program formatıdır. Radyo Çocuk Kulübü'nün programı, konserler, şarkılar, masallar, temsiller ve çocukların eğitimine yönelik konuşmalardan oluşmaktadır. Programda öne çıkan konuların başında müzik çalışmaları gelmektedir.

$\mathrm{Bu}$ araștırma, 1941 yılında faaliyetlerine başlayan Radyo Cocuk Kulübü'nün yayın içeriği ve amaçları üzerinedir. Küçük bir topluluk olarak başlayan Radyo Çocuk Kulübü, Neriman Hızır tarafindan kurulmuș, daha sonra sayı olarak artarak, radyo çocuk tiyatrosu ve çocuk korosunun da kurulduğu bir programa dönüşmüştür. Koronun repertuvar seçimi ve çalıștırılması dönemin konservatuar mezunlarından besteci, Nedim Otyam tarafından yürütülmüștür.

Araștırmada doküman incelemesi modeli kullanılmıs olup, 1941 1949 yılları arasında yayınlanmış Radyo dergisinin, Radyo Çocuk Kulübü ile ilgili yazıları incelenmiștir. Ayrıca Radyo Cocuk Saat'inde söylenen 25 çocuk şarkısı; ritim, tempo, dizi, tek seslilik ve çok seslilik uygulamaları bakımından incelenmiştir. İncelenen cocuk sarkılarından 4 tanesi halk ezgisi, 21 tanesi ise Halil Bedii Yönetken'e ait orijinal kompozisyonlardır. Sonuç olarak Radyo Cocuk Kulübü, radyo yayıncılığı bağlamında çocukların eğitimi için tasarlanan ilk sistemli ve uzun soluklu programdır. Müzik etkinlikleri, Radyo Çocuk Kulübü'nün çalışmalarının önemli bir kısmını olusturmaktadır. Radyo Cocuk Kulübü Korosu, radyo kapsamında kurulan çocuk korolarının öncüsü ve sistemli çalışan ilk örneğidir. Radyo Cocuk Kulübü programının içeriği ve söylenen șarkılar, Cumhuriyet ideolojisinin kimlik inşasında, çocukların nasıl ele alındığını gösteren önemli bir yayın formatıdır.

Anahtar kelimeler: Radyo Dergisi, Radyo Çocuk Kulübü, Nedim Otyam, Neriman Hizır, Koro

\begin{abstract}
Radio Kids Club is not just an entertainment program; it is an important program format that shows how the radio handled the children's education of the period. The program of Radio Kids Club consists of concerts, songs, fairy tales, performances and speeches for the education of children. Music studies are the leading topics in the program.
\end{abstract}

This research is about the content and objectives of the Radio Kids Club, which started its activities in 1941. Radio Children's Club, which started as a small community, was founded by Neriman Hizir, and later increased in number, and turned into a program in which radio children's theater and children's choir were established. Chorus's repertoire selection and employment was conducted by Nedim Otyam, a composer graduate of the period.

The document review model was used in the research, and the articles of the Radio magazine, published between the years 1941 and 1949, about the Radio Children's Club were examined. In addition, 25 children's songs sung in Radio Children's Clock; Rhythm, tempo, scale, monophonic and polyphonic practices were examined. 4 of the children's songs examined are folk melodies and 21 are original compositions of Halil Bedii Yonetken. As a result, the Radio Kids Club is the first systematic and long-term program designed for the education of children in the context of radio broadcasting. Music events constitute an important part of the activities of the Radio Kids Club. Radio Children's Club Choir is the pioneer of the children's choirs established within the scope of the radio and the first example of working systematically. The content of the Radio Kids Club program and the songs sung are an important broadcasting format that shows how children are handled in the identity building of the Republic ideology.

Keywords: Radio Magazine, Radio Kids Club, Nedim Otyam, Neriman Hizir, Chorus

\section{Giriş}

Radyo, Cumhuriyet'in ilk yıllarından itibaren etkin bir propaganda aracı olarak karşımıza çıkmaktadır. "Televizyonun henüz insanların gündelik hayatını bu kadar işgal etmediği, okuma yazmanın bu denli yaygın olmadığı ve gazete basıp dağıtmanın da o kadar kolay olmadığı dönemlerde radyo, en etkili kitle iletişim aracıydı" (Kuruoğlu, 2006, s. 8). Vedat Nedim Tör, radyonun kitlelere ulaşmadaki gücünü, "Hiç şüphesiz ki, radyo zamanımızın en kuvvetli, en verimli bir yayın vasıtasıdır. Aynı yerden ve aynı zamanda, sınır içi ve sınır dışı milyonlara hitap edebilmek, düşünülürse, korkunç bir kuvvettir” (Tör, 1942, s. 15) şeklinde özetlemektedir. Tör'ün ifadelerinden anlaşılacağı üzere radyo, dönemin en güçlü iletişim aracı olarak sunduğu imkânlar doğrultusunda devletin oldukça etkin kullandığı bir aygıttır. Türkiye'de radyo, ilk yıllarından itibaren etkin bir propaganda aracı olmasının yanı sıra, eğitim-öğretim faaliyetlerini destekleyici bir araç olarak değerlendirilmiştir. Bu bağlamda yabancı radyo yayınlarının eğitim- öğretim ve propaganda faaliyetleri bakımından incelenmiştir. 
Radyodan okullarda öğrenim, öğretim ve eğitim işlerinde faydalanılması, radyo kullanılmağa başlandığı zamanlardan beri girişilmiş bir iş olmakla beraber, bu teşebbüsler asıll 1930 yılından sonra verimli olmağa başlamıştır. Gerçekten, 1926'da Çekoslovakya Radyosu, Masaryk (Masarick) Enstitüsü’nün de işbirliğini temin ederek, halkın yetiştirilmesinde faydalı olacak öğretim saatleri ihdas eylemişti. Bu başlangıcı İsviçre, İsveç ve İtalya takip etmiş, Almanya da bu memleketleri az zamanda taklide girişmişti (Ertuğ, 1945, s. 1)

Kitlelerin eğitimi ve örgütlenmesi için faaliyet yürütün ülkelerin, bizim radyo yayıncılığımızın şekillenmesinde önemli bir role sahip olduğunu söyleyebiliriz. Radyonun gücünün farkında olan devlet yöneticileri bu alandaki gelişmeleri yakından takip etmiştir. "Türkiye'de ilk resmi radyo yayınının 6 Mayıs 1927 yılında başladığını belirten Kütükçü (2012, s. 27), dünyada ilk düzenli radyonun yayın hayatına 1920’de başladığı düşünüldüğünde, Türkiye'ye radyonun neredeyse batılı örnekleri ile eş zamanlı geldiğini belirtmektedir.”

Türkiye'de radyo yayınlarının düzenli ve teknik olarak dünya standartlarında yayın yapan bir boyut kazanması ise Ankara Radyosu'nun kurulduğu 1940’lı yıllarda gerçekleşmiştir. “Bu yıllarda devlet, radyonun önemini daha iyi kavramış, radyonun kendi yararları doğrultusunda kullanılabilecek bir araç olduğunun bilincindedir (Cankaya, 2003, s. 31). Bu dönem yapılan yayınlara bakıldığında radyo sadece bir eğlence aracı olmanın ötesinde; telkin, bilgilendirme ve terbiye vasıtası olarak düşünülmüştür. Başka bir deyişle radyo dönemin yaygın eğitim kurumlarını destekleyen ve halkı eğitmeyi amaçlayan bir kitle iletişim aracıdır. 1940'lı yıllarda radyo programlarının önceki yıllara göre daha düzenli ve gelişmiş olduğunu belirten Kocabaşoğlu (1980) bu durumu şu şekilde değerlendirmektedir:

$\mathrm{Bu}$ dönemde yayın saatleri ve süreleri, programların yayınında görülen düzenlilik ve programların dinleyiciye sunuluşunda gözlenen olumlu gelişmeler yönünden erginleşmiştir. İkinci olarak, özellikle 1941 yılından başlayarak, radyo programlarında dinleyici kümelerine göre bir farklılaşma olmuștur. Başka bir deyişle radyo programlarının hazırlanmasında yaş, cinsiyet, meslek vb. özellikler geçmişe oranla daha çok dikkate alınır olmuştur. Üçüncü olarak, gerek radyo bir örgüt olarak, gerekse radyoculuk bir uğraş olarak kurumsallaşmaya başlamıştır (s. 249).

1940’l1 yıllarda hemen her konuda yayın yapan Ankara Radyosu yayınları içerisinde müzik programlarına oldukça geniş bir yer ayrılmıştır. "Radyo yayınlarının 2/3'ünü müzik yayınları oluşturmaktadır. Müzik yayınlarının bir başka özelliği ise söz yayınlarına oranla, çağdaş radyoculuğa daha uygun yöntemlerle hazırlanıp sunulmuş olmasıdır" (Kocabaşoğlu, 1980, s. 214).

Özellikle Avrupa ülkelerinin radyo programlarının incelendiği 1940’lı yıllarda Ankara radyosu, müzik yayınlarını daha planlı ve özenle hazırlamaktadır. Kocabaşoğlu (1980), radyonun müzik yayınları ile ilgili izlenen politikayı "Devletin ne denli müzik politikası var idiyse, radyonun da o denli vardı" şeklinde özetlemektedir (s. 214). Cumhuriyet'in ilk yıllarından itibaren müzik politikalarında egemen olan, Gökalp'in Milli Musiki hakkındaki görüşleridir. Gökalp'in işaret ettiği Milli Musiki görüşünün temel dayanak noktası halk ezgilerinin, Batı tekniğiyle çok seslendirilmesi sonucunda ulaşılacaktır.

...millî musikimiz memleketimizdeki halk musikisiyle garp musikisinin imtizacından doğacaktır. Halk musikimiz, bize birçok melodiler vermiştir. Bunları toplar ve garp musikisi usûlüne armonize edersek, hem millî, hem de Avrupai bir musikiye malik oluruz. Bu vazifeyi ifa edecek olanlar arasında Türk ocaklarının musiki heyetleri de dâhildir. İşte Türkçülüğün musiki sahasındaki programı esas itibariyle bundan ibaret olup, bundan ötesi millî musikarlarımıza aittir (Gökalp, 1968, s. 131).

Behar (2008), Cumhuriyet'in ilk elli yılında Gökalp'in sentezinin müzik politikalarında egemen görüş olduğunu belirtmektedir (s. 272). Dolayısıyla, radyo yayınlarının amacı ve içeriği Gökalp'in Milli Musiki görüşlerinden bağımsız değildir. Radyodaki müzik yayınları, dönemin müzik politikalarının radyodaki yansımasıdır. O dönem radyosunun müzik yayınlarının amacı şu şekilde belirtilmektedir. "Radyomuzun musiki neşriyatı bakımından bir hususiyeti hem umumî hem de garp musikisini hem de millî ve yerli musikimizi yaymak durumunda olmasıdır" ("Radyo çocuk", 1942, s. 21). Bakıldığında 1940'lı yıllardaki radyo müzik yayınlarında Klasik Türk Musikisi eserlerine yer veren bir yumuşama görülse de temel itibariyle Gökalp’in işaret ettiği Milli Musiki hedefi radyo yayınlarında da kendini hissettirmektedir.

Daha önce belirttiğimiz üzere devlet desteğiyle kurumsallaşan Ankara Radyosu, temelde bir eğitim vasıtası olarak düşünülmüştür. Müzik yayınlarında da temelde amaçlanan şey, halkın o dönem izlenen müzik politikaları doğrultusunda eğitilmesi ya da müzik dinleme alışkanlıklarının değiştirilmesiydi. Yani radyodaki müzik yayınları, müzik kültüründeki amaçlanan değişimin gerçekleşmesinde önemli bir araçtı. Dönemin önde gelen müzik adamlarından Saygun (1942), devlet eliyle yürütülen radyo yayınlarının ticari kaygı ile hareket edemeyeceğini ve radyonun bir terbiye vasıtası olduğunu belirtmektedir (s. 9). Devlet yönetiminde olan 1940'lı yılların radyosu, müzik programları bakımından son derece sistemli ve düzenli bir çalışma anlayışına sahiptir. 1940'lı yılların radyo müzik yayınlarına baktığımızda genel olarak, Musiki Neşriyat Şefliğine bağlı A, B ve C büroları altında faaliyet gösterdiği görülmektedir. Musiki Neşriyat Şefliği altında faaliyet yürüten A, B ve C büroları; "senfonik konserler, 
hafif musiki neşriyatı, dans musikisi, klâsik Türk musikisi, halk musikisi, karışık hafif Türk musikisi, oda musikisi, solistler, temsillerde musiki, çocuk saatinde musiki, musikili konuşmalar" ("Radyomuzda çocuk", 1941, s. 21) gibi her türlü müzik yayınının hazırlanmasından sorumludurlar.

Tablo 1

Radyo Musiki Neşriyat Şefliğine Bağlı Bürolar (“Radyo çocuk”, 1942, s. 21)

\begin{tabular}{|c|c|c|}
\hline A Bürosu Milli Musiki & B Bürosu Garp Musiki & C Bürosu \\
\hline $\begin{array}{l}\text { Şefliğin A bürosuna bağlıdırlar. Bu } \\
\text { sanatkârlar muayyen bir kadro içinde } 12 \\
\text { sazende ve } 25 \text { okuyucudan mürekkeptir. } \\
\text { Kendileri muayyen neşriyat saatlerinde } \\
\text { koro, fasıl sazı, kadınlar faslı, karışık } \\
\text { gruplar veya sololar halinde dinlediğimiz } \\
\text { bu sanatkârlar her gün tıpkı bir musiki } \\
\text { mektebinde olduğu gibi belli programla } \\
\text { çalışırlar. } \\
\text { Bu çalışmaların başlıca gayesi gündelik } \\
\text { neşriyat için ayrılmış zaman dışında daima } \\
\text { daha öğrenmek, temrin yapmak ve } \\
\text { repertuvarı çoğaltmak ve bilhassa ihtisas ve } \\
\text { mevzuları olan musiki nev'inde daha } \\
\text { zengin ve verimli bir halde bulunmaktır. }\end{array}$ & $\begin{array}{l}\text { Musiki neşriyat şefliğinin B bürosuna bağlı } \\
\text { teşekküller ve sanatkârlar da iki kısımdır. } \\
\text { Cumhur Başkanlığı orkestrasından ayrılmış } \\
\text { vasatî } 50 \text { kişilik radyo senfoni orkestrası, } \\
\text { muayyen şefler ile haftada iki gün program } \\
\text { kalıbındaki günlerde görülen konserlerini } \\
\text { verir. Cumhur Başkanlığı bandosu da aynı } \\
\text { şekilde neşriyata iştirak eder. Bu } \\
\text { teşekküllerin ait oldukları şeflerle } \\
\text { müştereken takarrür etmiş olan çalışma } \\
\text { tarzlarının herhangi bir sebeple değişmesi } \\
\text { veya gelişmesi için icabında radyodifüzyon } \\
\text { müdürünün başkanlığında musiki neşriyat } \\
\text { şefi, mütehassıs tonmaysterler ve } \\
\text { orkestraların şeflerinden mürekkep bir } \\
\text { (Musiki Müşavere Komitesi) toplanarak } \\
\text { karar verir. Radyo salon orkestrası, dans } \\
\text { orkestrası ile klasik oda musikisi grupları, } \\
\text { solistler vesaire musiki neşriyat şefliğince } \\
\text { doğrudan temin edilir. }\end{array}$ & $\begin{array}{c}\text { Muhasebe, muamelât (işlem), program, } \\
\text { sicil ve yazı işlerinin hazırlandığ } 1 \\
\text { yürütüldüğü kısımdır. }\end{array}$ \\
\hline
\end{tabular}

Radyo müzik yayınları görüldüğü üzere Türk müziği A şubesi ve Batı müziği B şubesi olmak üzere iki büronun sorumluluğu altında yürütülmekte ve $\mathrm{C}$ bürosu müzik programlarını ve görevli sanatçı personel ile ilgili her tür resmi yazışmanın yürütüldüğü birim olarak tasarlanmıştır. Yine C bürosuna bağlı plak ve radyo kütüphanesi, yapılacak banttan yayınların hazırlanmasını sağlamaktadır. "Plak yayınlarında amacın sadece eğlence olmadığı, dünyaca ünlü orkestra, oda müziği, solistleri ve karma konserlerin dinletilmesinin amaçlandığı belirtilmektedir" ("Radyomuzda çocuk", 1941, s. 22). Türk müziği yayınlarını hazırlayan A şubesinin konser programları düzenlemenin yanı sıra, ses ve saz sanatçılarının eğitiminin gerçekleştirildiği bir Türk müziği konservatuvarı gibi çalıştı̆̆ını söyleyebiliriz.

O dönem devlet denetiminde yürütülen radyo müzik yayınlarındaki nihai amaç, Milli Musiki hedefi doğrultusunda yayın yapmak ve uygulanan müzik politikalarının halk tabanında karşılık bulması şeklinde özetlenebilir. Bu bağlamda radyodaki bütün yayınlarda olduğu gibi, müzik yayınlarında da izlenen yayın politikası tamamen egemen siyasal gücün güdümündedir.

Radyonun öteki programlarında olduğu gibi, müzik yayınlarında da hükümet ve partinin (CHP) önde gelenlerince yapılan uyarı ve yönlendirmelerin müzik politikasında etkili olduğu söylenebilir. Nasıl ki Atatürk'ün 1934'te Meclisi açarken yaptığı konuşmada Türk müziğine ilişkin sözleri radyoda Türk müziğinin yasaklanması için işaret sayılmışsa, incelenen dönemde de Milli Şefin tutumu ya da CHP Genel Sekreterinin sözleri, radyonun müzik politikalarını belirleyen direktifler yerine geçmiştir (Kocabaşoğlu, 1980, s. 215).

Bu durumun sebebinin yine politik olduğunu, Kutluk'un (1997) “müzik ve politika her zaman iç içeydi” sözleriyle özetleyebiliriz (s. 7). Dolayısıyla araştırmaya konu olan Radyo Çocuk Kulübü, müzik yayınları bakımından o dönem izlenen müzik politikalarıyla doğrudan ilişkilidir. Radyo Çocuk Kulübü müzik programlarının düzenlenmesi, Musiki Neşriyat Şefliğinin yardımcı olduğu faaliyetler kapsamındadır.

\section{Yöntem}

Araştırmada doküman incelemesi modeli kullanılmış olup, "doküman incelemesi, araştırılması hedeflenen olgu ya da olgular hakkında bilgi içeren yazılı materyallerin analizini kapsar" (Yıldırım ve Şimşek, 2011, s. 187). Bu bağlamda, başta 1941-1949 yılları arasında yayınlanmış Radyo dergisinin, Radyo Çocuk Kulübü ile ilgili bütün yazıları ve konu ile ilgili dokümanlar incelemiştir.

\section{Bulgular}

\subsection{Radyo Çocuk Kulübü}

Türkiye'de radyo yayın tarihimiz bakımından Radyo Çocuk Kulübü, çocukların eğitimine yönelik ilk önemli programlardandır. 1941 yılından itibaren ortalama 9 yıl devam etmiş olan Radyo Çocuk Kulübü, kendisinden önce yapılan programlara göre daha sistemli ve çocuklara uygun bir şekilde kurgulanmıştır. Kocabaşoğlu (1980), daha önce yapılan programların çocuk eğitimine yönelik olduğunu ve aslında yetişkinlere hitap ettiğini belirtmektedir (s. 68). 
Bu bakımdan Radyo Çocuk Kulübü kendinden önce yayınlanan, çocuk eğitimine yönelik programlardan ayrı özelliklere sahiptir. "Bir kez çocuklara yönelik daha önce yapılan yayınlar rastgele yapılmıştır. Düzenli de olmayan bu programlar, değişik kişilere yaptırılmıştır. Zaman zaman kimi okulların çocuk korolarından yararlanılmıştır. Radyo Çocuk Kulübüyle çocuk yayınları ilk kez düzenli bir görünüm almıştır” (Kocabaşoğlu, 1980, s. 236).

Dönemin radyoculuk anlayışında yurt dışındaki örneklerin incelendiğini belirtmiştik. Aynı anlayışın çocuk programları bağlamında da sergilendiğini görmekteyiz. Radyoda eğitim faaliyetleri kapsamında Almanya, İngiltere, İsviçre, Kanada, Macaristan, Finlandiya, Polonya, İsveç, Çekoslovakya ve Danimarka gibi ülkelerin çocuklara yönelik yaptı̆̆

Tablo 2

Radyo Okul Programları ile İlgili Yurtdıșı Örnekleri ("Radyo okul”, 1949, s. 28-29)

\begin{tabular}{|c|c|}
\hline Ülke & Yayın İçeriği \\
\hline Almanya & $\begin{array}{l}\text { Eğitim Bakanlığı ve Stattgard (Stuttgard) Radyosundan maada, yüksekokullar, halk okulları ve köy okullar ile } \\
\text { şehir okullarını temsil etmek üzere bir radyo öğretim meclisi (conseil radio scolarie) kurulmuştur. }\end{array}$ \\
\hline & B.B.C $<<$ School broadcasting in Britain $>>$ adında bir broşür yayınlamıştır. İlk defa böyle bir eser yayınlayan Mç \\
\hline İngiltere & $\begin{array}{l}\text { Richard Palmer, Radio scolarie’nin bilhassa öğretim alanında müsbet tesirini müşahede etmiş ve okulla stüdyo } \\
\text { arasında daha sıkı bir işbirliği yapılmasının gerektiği kanaatine varmış bulunmaktadır. }\end{array}$ \\
\hline & 1946’da 33'ü ilkokul talebesine, 4'ü orta ve lise öğrencilerine, 1 tanesi de küçük çocuklara mahsus olmak üzere \\
\hline İsviçre & $\begin{array}{l}38 \text { emisyon yapılmıştır. Bu programlarda müzik yayınlarına fazla önem verilmiştir. } 10 \text { emisyon müziğe, } 9 \text { ilme, } 6 \\
\text { tarihe, } 6 \text { edebiyat ve tiyatroya, } 3 \text { coğrafyaya, } 1 \text { Noel bayramına, } 2 \text { emisyon da muhtelif konulara tahsis edilmiştir. }\end{array}$ \\
\hline Kanada & $\begin{array}{l}\text { Kanada ordusunun kontrolü altında bulunan Aklavik istasyonu yakınlarında okul bulunmaması yüzünden okula } \\
\text { gidemeyen çocuklar için terbiyevi programlar yayınlamaya başlamıştır. }\end{array}$ \\
\hline Macaristan & $\begin{array}{l}\text { Macar radyosu programı haftada beş saat 6-18 yaşındaki öğrencilere mahsus emisyonlar ihtiva eder. Bu } \\
\text { emisyonlar bilhassa uzaklarda oturdukları için büyük şehirlerin vasıtalarından istifade edemeyen 6-14 yaşındaki } \\
\text { ilkokul öğrencilerine tahsis edilmiştir. Müzik emisyonlarında çocuklara Händel'den Kodaly'ye kadar seçkin } \\
\text { parçalar dinletilir ve ayrıca izahat verilir. }\end{array}$ \\
\hline Finlandiya & $\begin{array}{l}\text { Finlandiya'nın yaz mevsimi için radio eğitim programı birçok muhtelif kısımları ihtiva eder. Fin dili (sözlü yazılı } \\
\text { dersler ve hikâyeler vs.), tabii tarih, müzik ve hıfzıssıhha. }\end{array}$ \\
\hline Polonya & $\begin{array}{l}\text { Lodz vilayetinde } 25 \text { okula radyo kurulmuştur. Başka okullara da kurulacak ve buralarda hususi tesisat } \\
\text { yapilacaktır. }\end{array}$ \\
\hline İsveç & $\begin{array}{l}\text { Okullar yüksek müdürlüğü son bahar ve kış radio öğretim programlarına bir (radio öğretim gazetesi) ilave } \\
\text { etmiştir. Bu gazete bugünkü hayatın bütün safhalarına temas eden ve her gün on beş dakika devam etmek üzere } \\
\text { yapılmakta olan bir program ihtiva eder. Atom enerjisi gibi fenni konulara mahsus programla } 15 \text { tarihi, } 5 \text { edebi, } \\
13 \text { fenni, } 10 \text { aktüalite, } 12 \text { müzik ve beden terbiyesi emisyonu vardır. }\end{array}$ \\
\hline Çekoslovakya & $\begin{array}{l}\text { Çekoslovakya'da 1947- } 1948 \text { yılı başlayan bu nevi yayınlar her gün saat 10,00-10,30 arasında yayın } \\
\text { yapılmaktadır. Çarşamba günü küçük dinleyiciler, Pazartesi günleri ilkokullar, Salı ve Cuma günleri ortaokullar } \\
\text { (haberler, müzik konuşmaları, aktüalite, edebiyat), Perşembe ve Cumartesi günleri de orta ve sanat okulları } \\
\text { (müzik tarihi, güzel sanatlar, aktüalite, montajlar) için yayın yapılır. } 4 \text { ilâ } 6 \text { yaşındaki çocuklar için geçen seneden } \\
\text { beri yapılmakta olan neşriyattan çok iyi neticeler elde edilmiştir. Bu emisyonlar çocukların dinleme ve düşünme } \\
\text { kabiliyetlerini inkişaf ettirmekte olduğundan Eğitim Bakanlığı çocuk yuvalarının teçhizat ve tesisatını ikmale } \\
\text { çalışmaktadır. }\end{array}$ \\
\hline Danimarka & $\begin{array}{l}\text { Eğitim Bakanlığınca teşkil olunan bir komisyon tarafından kontrol edilmekte olan eğitim programlarının tanzimi } \\
\text { devlet radyo idaresine verilmiştir. Bu işte } 17 \text { 'si öğretmen olmak üzere } 20 \text { kişi çalışmaktadır. Yayın programları } \\
\text { çok genişletilmiş ve muhtelif mevzular dâhil edilmiştir. }\end{array}$ \\
\hline
\end{tabular}

Ülkemizde de 1940'lı yılların radyo yayıncılığında, çocuk programlarının düzenlenmesi için Maarif Vekâleti bir komisyon kurmuştur. Komisyonun temel amacı çocuk programlarında radyodan ne şekilde istifade edileceği üzerine aşağıda belirtilen önemli kararları almıştır.

1-Radyoda çocuk programlarının tanzimi işi bir büroya verilmelidir. 2- Radyofonik çocuk tiyatroları diyaloglar, monologlar, masal ve efsane serisi, tabiat ve medeniyet âlemine ait pitoresk (göz alıc1) tasvirler, manzum ve mensur parçaların okunması, okumaların zaman zaman musiki ile karışık olarak yapılması, nebat ve hayvan alemine ait dikkate değer tecessüs uyandıran ve artıran cazip bilgiler, büyük adamların çocukluk hatıraları, çocuk koroları gibi konular ele alınmalıdır. 3- Radyodaki çocuk koro ve tiyatrolar için Musiki Muallim Mektebi ve Tiyatro Mektebi muallim ve talebelerinden yardım istenmelidir (Yeni Adam'dan aktaran Kocabaşoğlu, 1980, s. 237).

Bu bağlamda Radyo Çocuk Kulübü, işleyiş açısından bu komisyonun aldığı kararlarla oldukça benzer çalışmalar yürütmüştür. İşleyiş ve amaçları bakımından Radyo Çocuk Kulübü, sadece bir eğlence programı değil, çocuklara yönelik bir eğitim programıdır. 1949 yılına ait Radyo dergisindeki Müzik Terbiyeci ve Radyo başlıklı yazıda; "...hemen her ailenin evinde radyo gibi bir iletişim aracının varlığından bahsedilerek, radyodan sadece zevk ve eğlence aracı olmadığı ve çocukların müzik terbiyesinde etkin bir araç olduğu vurgulanmaktadır” (Soykut, 1949, s. 1).

Radyo Çocuk Kulübü'nün kuruluşu, 1941 yılına ait Radyo dergisinde şu şekilde anlatılmaktadır: "Radyo çocuk programı 19 Şubat 1941'den beri <<Radyo Çocuk Kulübü $>>$ adı ile bir şahsiyet kazanmıştır. Radyo Çocuk Kulübünün çalışkan üyeleri mikrofon başındaki küçükler, programları hazırlayıp idare eden de Ayşe Abla'dır" ("Radyomuzda çocuk", 1941, s. 18). 


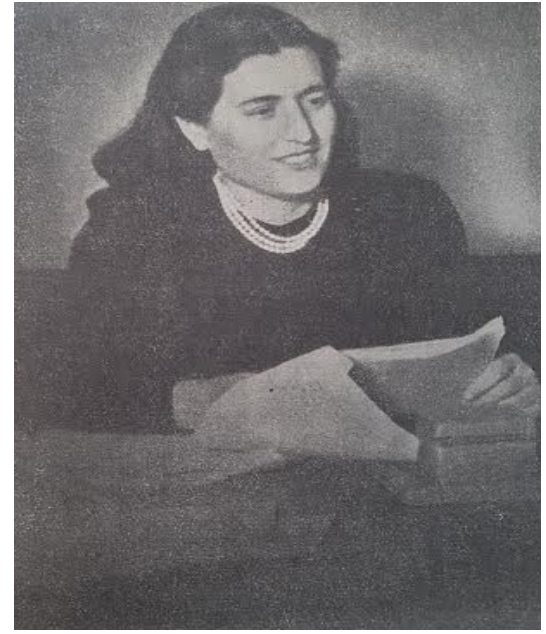

Görsel 2. Ayşe Abla, Neriman Hızır

Radyoda Ayşe Abla olarak bilinen Neriman Hızır Cumhuriyet'in ilk pedagoglarındandır. "Neriman Hızır: Erenköy Kız Lisesi, Arnavutköy Amerikan Kolejinde okumuş ve Amerika'ya gitmiştir. Orada dört sene muhtelif üniversitelerde çalıșmış ve en son Kolombiya Üniversitesinden çocuk gelişimi ve aile eğitimi üzerine uzmanlık diplomasını almıştır" ("Radyo çocuk", 1942, s. 11). "Neriman Hızır, Radyo Çocuk Saati programlarını bıraktıktan sonra Ankara Kızılırmak sokağında kendi adını taşıyan bir özel okul açtı ve bu konuda da öncülük görevini yerine getirmiş oldu" (Yazgan, 2015, s. 65). "Günümüzde de faaliyetlerini sürdüren Ayşe Abla Okulları Başkent Üniversitesi bünyesinde faaliyetlerini devam ettirmektedir.” ("Başkent Üniversitesi”, t.y.).

Radyo Çocuk Kulübü'nün dönemi içinde değerlendirdiğimizde, kendisinden önce gelen programlara göre ne derece sistemli bir topluluk olduğu, programı hazırlayan Neriman Hızır'ın aile eğitimi ve çocuk gelişimi uzmanı olmasından anlayabiliriz. Kulübün programlarını hazırlayan ve çalıştıran Neriman Hızır, Radyo Çocuk Kulübü'nde görev yapan çocukların hangi özelliklere göre seçildiğini şu şekilde belirtmektedir:

"Sesi radyoya elverişli ve neşeli olmak, kulağı bulunmak, yani bir havayı çabuk ve doğru olarak öğrenebilmek, düzgün şarkı söyleyebilmek, düzgün ve kolay okumak, fasih (açık ve düzgün) konuşmak ve en mühimi intikal sürati sahibi olmak" (Hızır, 1942, s. 30). Buradan da anlaşılacağı üzere Radyo Çocuk Kulübü’nde görev yapacak çocuklarda müzikal yetenek, teatral yetenek, iyi bir diksiyona sahip olmaları ve çabuk adapte olmaları gibi özellikler aranmaktadır. Dolayısıyla seçilen çocuklar sanki bir müzik veya tiyatro okuluna seçilen öğrenciler gibi yetenekleri doğrultusunda kulübün çalışmalarında yer almaktadır. Bunun temel nedeni ise, Radyo Çocuk Kulübü'nün hazırladığı programların büyük çoğunluğunda müzik ve tiyatro üzerine kurgulanmış olmasıdır. Neredeyse yapılan programların hepsinde çocukların rol yapabilmeleri ve şarkı söylemeleri gerekmektedir. Buradan yola çıkarak kulübün, çocuklar için tasarlanmış bir sanat kulübü olduğunu söyleyebilir. Hızır (1942), bu anlamıyla kulübü tanımlarken, “...biraz da Konservatuvara fidan yetiştiren bir limonluk vazifesi görüyor” tanımlamasını yapmaktadır (s. 31). "Kulübün hazırladığı ortalama 45 dakika süren her program için hazırlık süreci, sözlü kısımlar için dört saat, müzik kısmı için ise iki, üç saat gibi bir zaman almaktadır" "'Radyo çocuk", 1942, s. 11). Radyo Çocuk Kulübü’nün bir diğer önemli özelliği ise sadece Türkiye'de değil, farklı ülkelerdeki Türk çocuklarının takip ettiği bir program olmasıdır.

Radyo Çocuk Kulübü programlarını yalnız yurt içindeki Türk çocukları değil, yabancı ülkelerdeki Türk çocuklarının da büyük bir alaka ile takip etmektedirler. Kısa dalga üzerinden yayın yapan neşriyat, yurdumuzdan çok uzaklardaki Türk çocuklarını bile buradaki Türk kardeşleriyle Türkiye Radyo Çocuk Kulübünde bir araya getiriyor. Onlarda bizi yurttaki küçükler kadar, belki de daha büyük bir alâka ile dinliyorlar. Bilmece müsabakamıza iştirak ediyor, şarkı seçimlerine reylerini yolluyor, dileklerini bildiriyorlar ("Radyo çocuk", 1942, s. 22).

Zaman içerisinde sayı olarak artan Radyo Çocuk Kulübü, tiyatro ve müzik kısımları olmak üzere daha ayrıntılı bir çalışma anlayışı sergilemiştir. Kulüp bünyesinde üye sayısının artması doğal olarak bir çocuk korosunun kurulması ve bu koroyu çalıştıracak bir uzman bir müzik öğretmeni ihtiyacını doğurmuştur. Bu ihtiyacı karşılamak üzere koro çalışmaları için Nedim Otyam eğitmen ve koro şefi olarak dâhil olur.

Nedim Otyam, “1934'te Ankara Devlet Konservatuvarına girdi ve 1942 yılında diplomasını alarak Riyaseti Cumhur Filarmoni Orkestrasına atandı. Bir yandan da Ankara Radyosu Çocuk Saat'inde Nedim Ağabey takma adıyla küğ (müzik) işlerini düzenledi, çocuk korosunu yönetti. Ankara Halkevinde orkestra ve koro yöneticiliği yaptı. 1950 yılında İstanbul'a yerleşerek Atlas Film'in küğ yönetmenliğini yapmaya başladı ve bu sırada Türkiye'de ilk kez olmak üzere büyük orkestrayla seslendirilen film geri düzey küğü (film müziği) yazdı. 1952'de Barbaros Film'i kurarak film küğ çalışmalarına devam etti (Oransay, 1965, s. 63-63). 1974- 
1984 yılları arasında İstanbul Belediye Konservatuarının müdürlüğünü üstlendi. 1976'da Mimar Sinan Güzel Sanatlar Üniversitesi Sinema ve Televizyon bölümünde film müziği dersleri vermeye başladı; 1986 yılında emekliye ayrıldı. 6 Mart 2008 tarihinde İstanbul'da vefat etti ("Wikipedia", t.y.)..

Neriman Hızır, Nedim Otyam'ın Radyo Çocuk Kulübü Korosu'nun şefliğine nasıl geldiği ile ilgili şunları belirtmektedir:

O zamana kadar programın bütün diğer kısımları gibi şarkı kısmıyla da ben uğraşıyordum. Program ve temsilleri yazmak, çocukları çalıştırmak, üstelik de şarkıları seçip koroya öğretmek, bir insanın gücükle kaldırabileceği bir iş halini aldı. İşte o aralık, koronun bugünkü Nedim Ağabeysi imdadıma yetişti. Nedim Otyam o zaman henüz konservatuvarda talebe idi. Çocukları çok sevdiğini, onlarla çalışmaktan zevk duyduğunu hissedince, kendisinden benim çocuklarım da şarkı çalışmalarına yardım etmesini rica ettim. Nedim Otyam o zamandan beri çocukların sevgili Nedim Ağabeysi oldu (Hızır, 1943, s. 12)

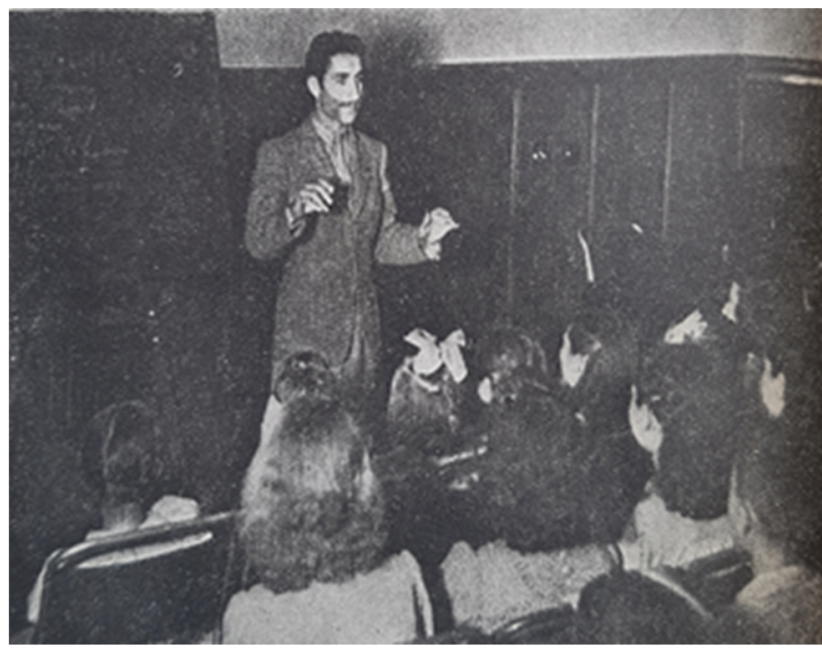

Görsel 2. Radyo Çocuk Kulübü müzik öğretmeni Nedim Ağabey’lerinin idaresinde prova yaparken

Nedim Otyam'ın çocuk korosunu çalıştırmaya başlaması ile birlikte, Radyo Çocuk Kulübü artık daha sistemli çalışan bir koro haline dönüşmüştür. İlerleyen yıllarda Radyo Çocuk Kulübü, Milli Eğitim Bakanlığına bağlanarak, Radyo Çocuk Saati ismiyle yayınlarına devam etmiştir.

Basın Yayın ve Turizm Genel Müdürlüğü yasası uyarınca 1950 yılında toplanan Radyo Yayınları Danışma Kurulu, Çocuk Saati'nin Milli Eğitim Bakanlığınca yönetilmesi için adı geçen bakanlığa başvurulmasını kararlaştırmıştır. Bakanlığın başvuruya olumlu karşılaması sonucu, Çocuk Saati'ni hazırlama görevi dört kişilik bir komiteye verilmiştir. Dört üyeden oluşan bu komisyonda Çocuk Saati'nin baş sorumlusu Mükerrem Kamil Su, yabancı radyoları dinleyip bilgi sağlamakla görevli Şevket Türkyılmaz, müzik yayınlarını düzenlemekle görevli Halil Bedii Yönetken ve komisyonla radyo arasındaki ilişkileri sürdürmekle yükümlü Ümit Halit Demiriz yer almıştır (Kocabaşoğlu, 1980, s. 325).

Radyo Çocuk Kulübü radyo yönetiminin yetki alanından çıkarılmasıyla, Radyo Çocuk Saati olarak yayınlarına devam etmiştir. "Böylece Çocuk Saati'nin yönetimi, dokuz yıllık bir uygulamadan sonra radyodan alınarak Milli Eğitim Bakanlığı'na verilmiş oluyordu” (Kocabaşolu, 1980, s. 325-326). Bu gelişme ile ilgili ne tür bir resmi gerekçe sunulduğu bilinmemesine rağmen, Radyo Çocuk Kulübü’nün kurucusu Neriman Hızır, "bu değişikliğin altında solculuk suçlamalarının yer aldığını, örneğin bir Macar çocuk öyküsünde çocukların Kırmızı Ceketliler, Siyah Ceketliler diye ayrılmasının komünizm propagandası olarak değerlendirildiğini belirtmektedir" (Kocabaşoğlu, 1980, s. 326). Bu durum ile ilgili Yazgan'a (2015) ait benzer bir anlatımda;

1940’lı ve 1950'li yıllar aynı zamanda Dünya'da ve Türkiye'de Birlerşik Amerikalı Senatör Mc. Carthy'nin estirdiği, sözüm ona Komünist Avcılı̆̆ dönemiydi. İște o yıllarda, 1947 yılının ortalarında, sözde Ayşe Abla çocuk şarkılarıyla Rusya'ya şifreli mesajlar falan gönderdiği öne sürülmektedir. Ayşe Abla, yani Neriman Hızır, epey sıkıntılı günler geçirmiş olabilir. Allah akıl fikir versin... Başka ne denebilir? (s. 68).

$\mathrm{Bu}$ konu ile ilgili elimizde resmi bir belge olmadığını da belirterek, çocuk programlarında yetkinin tamamen bakanlığa devredilmesini egemen siyasal otoriterin, bütün yetkiyi kendisinde topladığı bir uygulaması olarak değerlendirebiliriz. Yani radyo yürütülecek çocuk programlarında bakanlığın onayından geçecek sıkı bir denetim söz konusudur. Radyo Çocuk Saati, Milli Eğitim Bakanlığı denetiminde, "programlarda yer alacak söz metinlerinin ve müziklerin kontrol yetkisini komiteye vermiştir” (Kocabaşoğlu, 1980, s.326). 


\subsection{Radyo Çocuk Saati İle İlgili Dinleyici Memnuniyeti}

Radyo yayınlarının niteliği ve dinleyicilerin yayınlar hakkındaki düşüncelerini öğrenmek üzere, 1948 yılında Türkiye Radyo Postaları ve İstatistik Umum Müdürlüğü'yle birlik te Türkiye çapında bir anket çalışması yürütmüştür. 6639 dinleyicinin katıldığı ankete verilen cevaplar doğrultusunda yayın politikalarını gözden geçirmeyi amaçlayan Ankara Radyo'sunun yaptığı ankette Radyo Çocuk Saati ile ilgili bölümü şu şekildedir.

Tablo 3

Çocuk Saati ile ilgili dinleyici görüşleri ("Radyo anketimiz", 1948, s. 45)

\begin{tabular}{lcc}
\hline Çocuk Saati Hakkında ne düşünüyorsunuz? & Katılımcı (f) & $\mathbf{\%}$ \\
\hline Cevap vermeyenler & 2050 & $\% 30.8$ \\
Beğenenler & 3557 & $\% 53.5$ \\
Beğenmeyenler & 549 & $\% 8.3$ \\
Arttırılmasını isteyenler & 160 & $\% 2.5$ \\
Azaltılmasını isteyenler & 77 & $\% 1.1$ \\
Kaldırılmasını isteyenler & 48 & $\% 0.8$ \\
Daha geç saate alınmasını isteyenler & 198 & $\% 3.0$ \\
Toplam & 6639 & 100 \\
\hline
\end{tabular}

Resmi birer veri olarak değerlendirdiğimiz anketin, cocuk programlarına ilișkin soruya verilen cevaplara bakıldığında, o dönem dinleyicilerinin \% 53,5 gibi büyük oranda programdan memnun oldukları görülmektedir. $\mathrm{Bu}$ beğeni oranı radyoda düzenlenen bir program için, sadece o günlerde değil günümüzde bile yüksek bir başarı olarak değerlendirilebilir. Memnun olmayanlar ise \% 8,3 gibi çok az bir dinler kitleyi temsil etmektedir. Ayrıca programın süresinin uzatılmasını isteyenler 160 kişi $\% 2.5$, azaltılmasını isteyenler ise 77 kişi $\% 1.1$ gibi bir oranla ortalama iki katı dinleyici programın süresinin uzatılmasını istemektedir. Programın kaldırılmasını isteyen seyirciler en düşük oranla $\% 0.8^{\prime}$ dir.

\subsection{Radyo Çocuk Kulübü Programı}

Kulübün faaliyetlerini incelediğimizde düzenli bir program anlayışı vardır. Çocukların faaliyet gösterdikleri alanları, "1- Konserler, 2- Şarkılar, 3- Masallar, 4- Temsiller, 5- Faydalı konuşmalar, 6- Bunların dışındaki neşriyat" (Hızır, 1944, s. 11) olarak kurgulanmıştır.

\subsubsection{Konserler}

Bu başlık altında yapılan çalışmalar genel olarak, profesyonel sanatçılar ve küçük müzisyenlerin verdiği konserler şeklinde gerçekleşmektedir. Ayrıca bu konserlerde çalgılar ile ilgili bilgi verilmesi de amaçlamaktadır. “...dinletilen aletler, yalnız (solo) ya da birkaç müzik aleti bir araya gelerek, piyano, keman, viyolonsel, harp (arp), ağız armonikası, gitar ve bağlama olmuştur (Hızır, 1944, s. 11). Dönemin müzik politikalarının bir yansıması olarak dinletilen çalgılar, çok sesliliğin esas olduğu ağırlıklı olarak Batı müziğine ait çalgılardır. "Radyo Çocuk Kulübü Korosu şefi Nedim Otyam'ın 25 kişilik orkestra ile hazırladığı konserler de vardır” (Hızır, 1944, s. 11).

\subsubsection{Sarkılar}

Şarkılar başlığı altında yapılan çalışmalarla ilgili, "kulüp programının en esaslı kısımlarından birisi olduğu ve Radyo Çocuk Kulübü Korosu'nun sıkı bir disiplin altında çalışarak her haftaki programında en az bir tanesi yeni olmak üzere, 10-15 dakikalık şarkılar hazırladığı belirtilmektedir” (Hızır, 1944, s.11). Radyo Çocuk Kulübü'nün söylediği şarkıların büyük oranda Nedim Otyam'a ait besteler ve yanı sıra o dönem çocuk şarkıları yazan diğer isimlere ait olduğunu söyleyebiliriz.

$\mathrm{Bu}$ dönem bestelenen çocuk şarkıları marşlar, tonal şarkılar, aktarma şarkılar (başka dilden tercüme veya var olan melodiye Türkçe söz yazma), halk türküleri ve halk müziği ses dizilerinden faydalanılarak bestelenmiş çocuk şarkılarından oluşmaktadır. Şarkılarda sıklıkla milliyetçi ögeler, Türklük kavramı ve ulus olma gibi ögeler ön plandadır. Aşkın, bu dönem bestelenen çocuk şarkıları ile ilgili düşüncelerini, "yeni bir ulus yaratma sevdasında olan bir ülke için doğru bir politikaydı... Karizmatik bir lider etrafında bir ulusa yaratılıyorsa bunların olması gerekiyordu. Bu liderle övünerek kimlik bilincinin oluşturulmaya çalışıldı, strateji buydu" (Kutluk ve Aşkın, 2016, s. 166-167) şeklinde belirtmektedir.

Satır ve Reyhan (2018), erken Cumhuriyet dönemi çocuk şarkılarında Türk kimliği üzerinden "irki bir nitelik taşıyan soy, vatan, bayrak, savaş-askerlik, Atatürk, ekonomi ve İsmet İnönü” gibi konuların yer aldığını belirtmektedir (s. 213). Dolayısıyla cumhuriyetin ilk yıllarından itibaren bestelenmiş çocuk şarkıları, sıradan sözler üzerine bestelenmiş şakılar değil, ideolojik düşüncenin benimsetilmesi için üretilmiş araçlardır. Başka bir deyişle bestelenen şarkıların sözleri alegorik metinler ve şiirlerdir. Alegori, "bir sanat eserindeki ögelerin gerçek hayattan bir şeyleri temsil etmesi durumu” (Akalın, 2011, s. 88) şeklinde tanımlanmaktadır. “...metinlere ilişkin yapılacak değerlendirmede öncelikli olarak söylenebilecek şey, ideolojinin alegoriler üzerinden anlatılma çabasıdır. Metinlerin neredeyse tamamına yakını Cumhuriyet'in ilke ve devrimlerine olan bağlılı̆̆ı pekiştirmek, bu değerlere 
ters düşebilecek her şeyi eleştirmek/yermek ve halka güven aşllamak üzerinedir” (Aydemir, 2017, s. 129). Bu dönem çocuk şarkılarının bir diğer karakteristik özelliği ise, tonal ve modal çok sesliliğin ön plana çıkarılmasıdır.

\subsubsection{Masallar}

Masallar kapsamındaki çalışmalar Radyo Çocuk Kulübü’nün önemsediği etkinliklerdir. Bu masallar türlerine göre şu şekildedir:

...hayvan masalları, halk masalları, peri masalları, ahlaki masallar, milli kahramanlık masalları, halk masalları, çeşitli efsaneler ve klasik mitoloji gibi her tip çocuk masallarıdır. Bunlardan Kendi Başına Dolaşan Kedi ve Lâle Masalı'nda olduğu gibi birkaç tanesi baştan sonuna kadar piyanonun yardımı ile anlatılmıştır. Bu tarzın çocukların hoşuna gittiği zannolunduğundan ilerisi için bu tip birkaç masal daha hazırlanmaktadır (Hızır, 1944, s. 11).

Seçilen masallar konuları itibariyle, çocuklara yönelik birer terbiye vasıtasıdır. Öne çıkan bir diğer özelik ise Radyo Çocuk Kulübü masallar başlığı altında yapılan yayınlarını da müzik eşliğinde sunulmasıdır. “...temsilin o andaki hissi çerçevesini yaratan bir sükûnet, heyecan, matem veya zafer havasını dinleyiciye sıkıcı bir diyalog şeklinde takdim edilmemelerine teneffüs ettiren, arka planda kalan ve temsile refakat eden müziktir" ("Radyo temsilleri”, 1948, s.21).

\subsubsection{Temsiller}

Temsiller başlığı altında yürütülen faaliyetlerde türlerine göre belli bir program takip edilmiştir. Temsil programları milli temsiller, tanınmış büyük adamların hayatları, seri temsiller, masal temsilleri, şarkılı temsiller, manzum temsiller şeklinde kurgulanmıştır.

Milli temsillerin sunumunda, "milli mevzuların karşılıklı konuşma ve izahlar yoluyla daha etkili olacağı düşünülmüştür" (Hızır, 1944, s.11). Tanınmış sanat ve bilim adamlarının hayatları kapsamında "Mozart, Mimar Sinan, Thomas Edison ve Barbaros Hayrettin gibi önemli kişilerin hayatlarını konu alan piyesler oynanmıştır" (Hızır, 1944, s.11). Seri temsillerde dünya çocuk edebiyatından seçilmiş örneklere yer verildiği ve kulübün ilk temsili Pinokyo olduğu ifade edilmiştir. Buradan elde edilecek tecrübeler doğrultusunda bu tip temsillere devam edileceği belirtilmektedir (Hızır, 1944, s.11). Masal temsilleri ise bir önceki başlıkta ele alındığı gibi çocukları ilgisini çekecek yerli ve yabancı masallardan oluşmaktadır.

Şarkılı temsiller ise Radyo Çocuk Kulübü'nün daima seslendirdiği bir tür olmuştur. "Ayrıca müzikli demiyoruz, çünkü Radyo Çocuk Kulübü, temsillerin geçit yerlerinde gonk sesi yerine daima müzik kullanma âdetini benimsemiş ve öne sürmüştür. Pamuk Prenses, Rüya, Faydalı Hayvanlar, Deli Deli vb. müzik ve şarkı bakımından ayrıca zengin olan bir takım temsillerdir" (Hızır, 1944, s.11). Şarkılı temsiller için özel olarak müzik bestelendiği ya da var olan eserlerin bu oyunlar için tekrar düzenlendiği söylenebilir.

Manzum piyesler ise sadece düz yazı olarak oynanan temsillerdir. "Radyo Çocuk Kulübü'nde görev alan çocukların bu tür temsillerden çok hoşlanmadığı ama seyircilerden gelen istekler doğrultusunda devam edildiği belirtilmektedir. Bütün bu tipler bir arada olmak üzere 104 temsil yapılmış, bu temsillerden 41 tanesi seyircilerden gelen metinlerdir." (Hizir, 1944, s. 11).

\subsubsection{Faydalı Konuşmalar}

Faydalı konuşmalar adından da anlaşılacağı üzere, çocuklara çeşitli konularda bilgi ve eğitim vermeyi amaçlayan bir bölümdür. Bu bölümde işlenen bazı konular, "Karıncanın hayatı, arıların hayatı, kutup seyahatleri tafsilatı (açıklamaları), matbaa tarihi, demiryolculuk hakkında konuşma, radyo evini gezme, kazalar programı, Bursa seyahati, Ziraat konuşmaları vb.dir. Bunlar dışında birkaç bilmece şeklinde tabiat bilgisi konuşması yapılmıştır" (Hizır, 1944, s. 11).

\subsubsection{Bunların Dışındaki Yayınlar}

Yukarıdaki konular dışında ele alınan her türlü yayınlar bu başlık altında toplanmıştır. "Küçüklerin yarım yamalak okudukları şiirler, birkaç monolog, bilhassa milli günler münasebetiyle söz korosu halinde okunan milli şiirler. Bilmece müsabakası, vilayetler arası ağaç dikme yarışı, yüz lira para ödüllü yazı yarışması, karagöz ve programlarda daima mevzuları birbirine bağlamak vazifesi gören terbiyevi konuşmalar” (Hızır, 1944, s. 11).

\subsection{Radyo Çocuk Kulübü'nde Söylenen Şarkılar}

Oransay’a göre, bu dönem pek çok çocuk parçası bestelemiş olan Nedim Otyam'ın eserleri arasında Çocuk Küğleri (Oransay, 1965, s. 63) başlıklı bir esere yer vermiştir. Fakat araştırmamız kapsamında bu eserin basılı haline ulaşılamamıştır. Fakat 1953 yılına ait dönemin önemli isimlerinden Halil Bedii Yönetken'in 25 Çocuk Şarkısı (Radyo Çocuk Saatinde Söylenen Şarkılardan) başlıklı eseri, radyoda söylenen çocuk şarkıları hakkında oldukça fikir vermektedir. 
Yönetken, eğitimci, folklorcu, müzik yazarı, flüt sanatçısı ve eğitim müziği bestecisi...1917'de İstanbul Muallim Mektebi'ni bitirmiş, mesleğine İstanbul ve Bursa'daki çeşitli okullarda müzik öğretmenliği yaparak başlamıştır. 1928'de devlet bursuyla Çekoslovakya’ya gönderilen Yönetken, Prag Konservatuarı'nda müzik eğitimi öğrenimi yapmış, çalışmalarını Paris ve Berlin'de kurslara katılarak sürdürmüştür. Ankara'da Musiki Muallim Mektebi’nde ve Ankara Lisesi’nde müzik öğretmeni olarak çalışmış, 1936'da Ankara Devlet Konservatuarı'nın kurulması üzerine bu okulda teori, solfej ve koro dersleri vermiştir. 1938'den itibaren Gazi Eğitim Enstitüsü Müzik Şubesi’nde eğitimci olarak görev yapan sanatçımız, 1935 yılından itibaren düzenli folklor çalışmalarına katılıış, 1937-1951 yılları arasında Ankara Devlet Konservatuarı'nın gerçekleştirdiği halk müziği derleme çalışmalarında yer almıştır (Say, 2005, s. 647- 648).

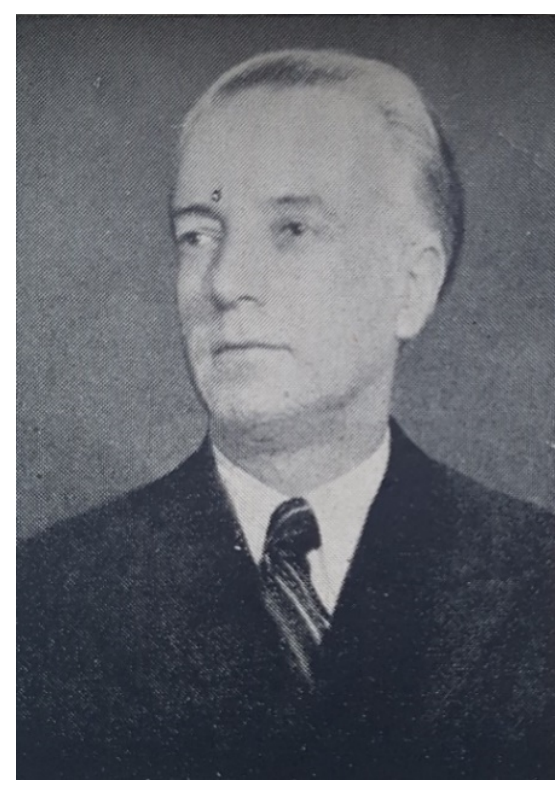

Görsel 3. Radyo Çocuk Saati Müzik Mütehassısı Halil Bedii Yönetken (Ankara Radyosu Çocuk Saati Çalışmaları, 1954)

İncelenen çocuk şarkılarının bestecisi Halil Bedii Yönetken, çocuklar şarkılarını beş kategoride siniflandirmaktadir.

Tablo 4

Kategorileri Bakımından Çocuk Şarkıları (Yönetken, 1966, s. 22).

1 Memleketin yerli bestecilerinin yarattıkları orijinal serbest şarkılar

2 Başka memleketlerin çocuk şarkılarından uluslararası değerde ve bestecilerin eserlerinden seçilerek dilimize adapte edilmiş şarkılar

3 Anonim çocuk ezgilerinden seçilmiş şarkılar

4 Halk ezgilerinden seçilmiş şarkılar

5 Çocuk ve halk ezgileri üslubunda bestelenmiş şarkılar

İncelenen kitapta bestelerin tamamının Halil Bedii’ye ait olduğu belirtilmiştir. Toplam 25 çocuk şarkısı bulunan kitaptaki şarkılar kategorileri ve müzikal özelliklerine göre şu şekilde sınıflandırılabilir.

Tablo 5

Orijinal Serbest Şarkılar (Yönetken, 1953, s. 5- 27)

\begin{tabular}{|c|c|c|c|c|c|}
\hline Şarkının Adı & Tonal/ Modal Yapı & Ölçü & Tempo & Çok Seslendirme & Söz \\
\hline 1. Postaci & Fa Majör & $2 / 4$ & Neşeli & Var/ İki Sesli & H. B. Yönetken \\
\hline 2. Sonbahar & $\begin{array}{c}\text { İki farklı uyarlama Do Majör } \\
\text { ve Si Bemol Majör }\end{array}$ & $6 / 8$ & Ağırca & Var/ İki Sesli & H. B. Yönetken \\
\hline 3. Güz & Si Bemol Majör & $\mathbb{C}$ Sebare & Ağır ve Yaslı & Yok/ Tek Sesli & $?$ \\
\hline 4. Yeni Yil & Mi Minör & $9 / 8$ & Neşeli & Var/ İki Sesli & Bekir Altan \\
\hline 5. Kar & Mi Minör & $2 / 4$ & Canlı ve Neşeli & Yok/ Tek Sesli & $?$ \\
\hline 6. Kış & Fa Minör /La Bemol Majör & $3 / 4$ & $\begin{array}{c}\text { Sessiz ve } \\
\text { Ağırca }\end{array}$ & Var/ İki Sesli & İhsan İlhan \\
\hline 7. Ankara Kedisi & Do Majör & $2 / 4$ & Canlı ve Neşeli & Yok/ Tek Sesli & N. Sevin \\
\hline 8. Bayrak & Re Majör & $\mathbb{C}$ Sebare & $\begin{array}{l}\text { Ağır ve } \\
\text { Heybetli }\end{array}$ & Var/ İki Sesli & $\begin{array}{c}\text { Hasan Ali } \\
\text { Yücel }\end{array}$ \\
\hline 9. Orda Bir Köy Var Uzakta & Re Minör & $4 / 4$ & Marş Temposu & Var/ İki Sesli & Kutsi Tecer \\
\hline 10. 23 Nisan & Fa Majör & $2 / 4$ & Marş Temposu & Var/ İki Sesli & H. B. Yönetken \\
\hline 11. İlkbahar & Re Majör & $2 / 4$ & Neşeli ve Canlı & Var/ İki Sesli & H. B. Yönetken \\
\hline
\end{tabular}


Tablo 5'in devamı

\begin{tabular}{|c|c|c|c|c|c|}
\hline Şarkının Adı & Tonal/ Modal Yapı & Ölçü & Tempo & Çok Seslendirme & Söz \\
\hline 12. Küçük Kuş & Do Majör & $3 / 4$ & Tatlı, Yumuşak & Yok/ Tek Sesli & $?$ \\
\hline 13. Haydi Kirlara & Fa Majör & $2 / 4$ & Marş Temposu & Var/ İki Sesli & H. B. Yönetken \\
\hline 14. Yaz Gelince & Re Minör & $2 / 4$ & Canlı & Yok/ Tek Sesli & H. B. Yönetken \\
\hline 15.Ay Dede & Mi Minör & $3 / 4$ & Tatlı, Yumuşak & Yok/ Tek Sesli & $?$ \\
\hline 16. Vatan & Do Minör & $4 / 4$ & Marş Temposu & Var/ İki Sesli & H. F. Süerdem \\
\hline 17. Havacılık & Si Bemol Majör & $4 / 4$ & Marş Temposu & Var/ İki Sesli & H. F. Süerdem \\
\hline 18. Ankara & Mi Minör & $2 / 4$ & Marş Temposu & Var/ İki Sesli & ? \\
\hline
\end{tabular}

Kitapta incelenen şarkıların ağırlıklı olarak Halil Bedii Yönetken'in kendi orijinal kompozisyonları olduğu görülmektedir. Şarkılardan sadece 6 tanesi tek sesli (bkz. Ek 1), 12 tanesi (bkz. Ek 2) çok sesli bestelenmiştir. Çok sesli örneklerin tamamı çalgı eşliksiz iki sesli çocuk parçalarıdır.

Bu kategorideki şarkıların tamamı Batı müziği ses sistemine göre majör ve minör ses dizilerinde bestelenmiştir. Orijinal kompozisyonlar başlığında incelenen çok seslendirilmiş örneklerin hepsinde, Batı müziği çok seslendirme tekniği kullanılmıştır. Çok seslendirmede ağırlıklı olarak üçlü, altılı ve yedili aralıklar kullanılmıştır.

Yönetken, parçaların tempolarını belirtirken yabancı terimler kullanmaktan kaçınmış ve tempoları çocukların anlayabileceği şekilde Türkçe ifadeler kullanarak belirtmiştir. Ayrıca bu kategorideki parçaların bazıları dönemin önemli karakteristik örneklerinin başında gelen marş karakterinde (bkz. Ek 3) bestelenmiş çocuk şarkılarıdır.

Tablo 6

Çocuk ve Halk Ezgileri Üslubunda Bestelenmiş Şarkılar (Yönetken, 1953, s. 2-3-25)

\begin{tabular}{|c|c|c|c|c|c|}
\hline Şarkının Adı & Tonal/ Modal Yapı & Ölçü & Tempo & Çok Seslendirme & Söz \\
\hline $\begin{array}{l}\text { Küçük Ayşe } \\
\text { Küçük Asker }\end{array}$ & La Hüseyni & $9 / 8(2+2+2+3)$ & Yürükçe & Var/ İki Sesli & H. B. Yönetken \\
\hline Tatil Bitti Yaz Bitti & Re Buselik & $9 / 8(2+2+2+3)$ & Yürükçe & Var/ İki Sesli & H. B. Yönetken \\
\hline Denizler & Fa Nikriz & $6 / 8$ & Yürükçe & Var/ İki Sesli & H. B. Yönetken \\
\hline
\end{tabular}

Bu kategorideki şarkıların tamamının söz ve müziği Yönetken’e aittir. Halk ezgileri üslubunda bestelenmiş örneklerin hepsinde modal etki görülmektedir. Şarkıların çok seslendirmeleri dörtlü armoni sitemine göre yapılmıştır. Özellikle Denizler isimli parçanın çok seslendirmesinde kontrpuan tekniğinin kullanıldığı görülmektedir (bkz. Ek 3). Parçaların karar sesleri çocukların söyleyebileceği ses aralığına göre düzenlenmiştir. Tempoları belirtmek için yine çocukların kolay anlayacağı Türkçe ifadeler kullanılmıştır.

Tablo 7

Halk Ezgilerinden Seçilmiş Şarkılar (Yönetken, 1953, s. 28-30)

\begin{tabular}{|c|c|c|c|c|c|}
\hline Şarkının Adı & Tonal/ Makamsal Yapı & Ölçü & Tempo & Çok Seslendirme & Söz \\
\hline Mor menekşe & Fa Çargâh & $5 / 8(3+2)$ & $?$ & Var/ İki Sesli & $\begin{array}{l}\text { Anonim (Halk Türküsü } \\
\text { sözler değiștirilmiș) }\end{array}$ \\
\hline Atımı Bağladım & Re Nikriz & $2 / 4$ & Canlı ve Neşeli & Var/ İki Sesli & $\begin{array}{c}\text { Anonim } \\
\text { (Halk Türküsü) }\end{array}$ \\
\hline Sarı Zeybek & La Hüseyni & $9 / 8(2+2+2+3)$ & Yürük & Var/ İki Sesli & $\begin{array}{c}\text { Anonim } \\
\text { (Halk Türküsü) }\end{array}$ \\
\hline Daldalan & Mi Hüseyni & $5 / 8(2+3)$ & Yürükçe & Var/ İki Sesli & $\begin{array}{c}\text { Anonim } \\
\text { (Halk Türküsü) }\end{array}$ \\
\hline
\end{tabular}

Kitapta yer verilen halk ezgilerinin makamsal yapısı Mor Menekşe Çargâh, Atımı Bağladım Nikriz, Sarı Zeybek ve Daldalan ise Hüseyni makamıdır. Ölçülerin ritim yapısı ise sadece bir tanesi basit ölçü (2/4), diğerleri ise aksak ritim kalıplarıdır. Tempolarda Mor Menekşe türküsü için herhangi bir ifade kullanılmamış, diğer türkülerde ise anlaşılır Türkçe ifadeler kullanılmıştır. Ayrıca Mor Menekşe isimli türküde sözleri değiştirilmiştir şeklinde bir açıklama vardır. (bkz. Ek 4). Yönetken'in çocuklara öğretilecek halk ezgileri ile ilgili genel yaklaşımı şu şekildedir: "Özellikle anonim çocuk ezgilerinden ve halk ezgilerinden seçilmiş örnekler üzerinde titizce durmak lâzımdır. Bunların okulun havasını bozacak cinsten olmamasına dikkat etmelidir. Anonim çocuk ezgileri tekerlemeler ve halk ezgileri arasında okula alınmayacak örnekler mevcuttur" (Yönetken, 1966, s. 32). Aslında türkülerin sözlerini değiştirmek o dönem uygulanan müzik politikalarında ve radyoda tercih edilebilen bir yaklaşımdır. Türküler, dönemin müzik politikaları doğrultusunda birer terbiye vasıtası olarak görülmüş, müstehcen ve çocuklara uygun olmadığ 1 düşünülen konular içeren örneklerde sözlerinin değiştirilmesi gibi bir anlayış söz konusudur.

\section{Sonuc}

İkinci Dünya Savaşı yılları olan 1940’lı yıllarda, radyo devlet yöneticileri tarafından her türlü imkânsızlığa rağmen oldukça önemsenmiştir. Bu bağlamda radyo, dönemin iletişim teknolojileri bakımından etkin bir iletişim ve propaganda aracıdır. Bu gücün farkında olan devlet otoritesi radyoyu aynı zamanda bir eğitim aracı olarak görmüş ve bu kapsamda oldukça zengin içeriğe sahip programlar yapmıştır. Bu dönemde devlet destekli radyo yayıncılığı, 
çocuk programlarını ayrı bir formatta ele almıştır. Devlet yöneticileri radyoyu, çocuk eğitimi ve çocuklar üzerindeki yeni kültür tasarımının önemli bir aracı olarak görmektedir. Ankara Radyosu'nun kurulmasıyla yeni bir kimlik kazanan radyo, daha düzenli ve sistemli bir yayın anlayıșı sergilemiş, bu kapsamda çocuklara yönelik özel programlar düzenlemiştir. Başlangıçta sistemli olmayan çocuk programlarının, 1941 yılında Radyo Çocuk Kulübü’nün kurulmasıyla farklı bir kimlik kazandığı söylenebilir. Yurtdışındaki örnekleri ile benzer bir içeriğe sahip olan Radyo Çocuk Kulübü, pedagojik yaklaşımla hazırlanan ilk çocuk programıdır. Radyo Çocuk Kulübü temelde, Cumhuriyet ilke ve devrimlerinin radyo vasıtası ile aktarılmasını amaçlayan bir program formatıdır. Bu format kapsamında yürütülen her faaliyet, sadece bir eğlence aracı değil, aynı zamanda çocukların eğitilmesi amacıyla hazırlanmıştır.

Radyo yayıncılığı teknik olarak görsel olmadığı için, çocuk programlarında işlenen konuların daha çekici olabilmesi amacıyla müzikten oldukça etkili bir şekilde faydalanılmıştır. Radyo Çocuk Kulübü’nün yayın faaliyetlerinde temsil, masal, hikâye vb. konular ağırlıklı olarak müzikle birlikte kurgulanmıştır.

Doğal olarak devlet denetiminde yayın yapan Radyo Çocuk Kulübü, dönemin müzik politikalarıyla paralel bir anlayışta yayın yapmaktadır. Radyo Çocuk Kulübü müzik yayınları, o dönem oldukça etkin olan Gökalp'in çerçevesini çizdiği Milli Musiki anlayışını çocuklar özelinde ele alan ve müzik zevk ve terbiyesini bu yönde değiştirmeyi amaçlayan yayınlardır.

Radyo Çocuk Kulübü'nün, söylediği şarkılar ve sahneledikleri temsiller sıradan eserler değil, kurgulanmış özel olarak hazırlanmış eserlerdir. Bu dönem bestelenen çocuk şarkılarının ağırlıklı olarak genel karakteristiği, Türk kimliğini öne çıkaran, vatan, ulus ve milliyetçilik gibi kavramları birleştirici ögeler olarak ele alan parçalardır.

İncelenen çocuk şarkıları $(2 / 4,3 / 4,4 / 4, \mathbb{C}, 6 / 8,5 / 8,9 / 8)$ olmak üzere ritmik çeşitlilik bakımından oldukça zengindir. Şarkıların ağırlıklı olarak iki sesli bir şekilde bestelenmiş olması, çok sesliliğin hedef olarak belirlendiği, dönemin müzik politikalarının çocuk şarkıları bakımından bir örneklemini temsil etmektedir. İncelenen parçaların müzik eğitimi almış, nota bilen çocuklar ve profesyonel çocuk koroları için bestelendiği söylenebilir. Söylenen marşlar, çocuk şarkıları ve icra edilen konserler ağırlıklı olarak Batı müziği ses sistemiyle bestelenmiş çok sesli örneklerden oluşmaktadır. Ayrıca çocukların söylemesi için belirlenen halk türkülerinin de iki sesli düzenlemiş olması dönemin müzik politikalarının tipik bir örneğidir. Ayrıca kitapta verilen parçalar 4 halk türküsü dışında, Halil Bedii Yönetken'e ait orijinal kompozisyonlardır. Bu kapsamda kitapta verilen parçalar arasında adapte, tercüme ve anonim çocuk ezgilerine yer verilmemiştir. Bu kitapta yer alan parçaların tamamı Radyo Çocuk Korosu için özel seçilmiş bir repertuvardır.

Bu bağlamda Radyo Çocuk Kulübü Korosu, dönemin müzik politikaları doğrultusunda, o dönem bestelenen çocuk şarkılarının ve düzenlenen konserlerin yurt çapında duyurulması ve daha çok çocuğa ulaşması için düşünülmüş bir yaygın eğitim kurumu gibidir.

Radyo Çocuk Kulübü'nün kurucusu Neriman Hızır (Ayşe Abla) bu programa yaklaşık 9 yıl boyunca devam etmiştir. Daha sonra radyo programındaki ismini kullanarak, Ayşe Abla İlkokulu ve çocuk yuvasını açmıştır. Türkiye'de ilk kez film müziği besteleyen Nedim Otyam, radyoculuk tarihi bakımından da ayrı bir öneme sahiptir. Kuruluşunda ve çalıştırılmasında görev aldığı Radyo Çocuk Kulübü Korosu, Türkiye'de çocuk korolarının öncülerindendir. Otyam Radyo Çocuk Kulübü'nün hazırladığı müzik programlarının ve çocuk korosunun daha sistemli bir boyut kazanmasını sağlamıştır.

1950'li yıllara gelindiğinde programın ismi Radyo Çocuk Saati olarak değişmiştir. Radyo Çocuk Saati programının müzikle ilgili kısmının başına Halil Bedii Yönetken getirilmiştir. Radyo Çocuk Saati, 1950’li yıllarda Milli Eğitim Bakanlığı tarafından daha sıkı denetlenen bir yayın haline dönüşmüştür. Günümüzde iletişim araçları ve eğlence anlayışı oldukça değişmiş olmasına karşın, Radyo Çocuk Kulübü ile benzer bir işleyişe sahip olan Radyo Çocuk Saati, karma bir program sergileyerek çalışmalarını günümüzde de devam ettirmektedir. Radyo Çocuk Kulübü Korosu, TRT bünyesinde faaliyet gösteren çocuk korolarının da öncüsü olarak değerlendirilebilir.

\section{Kaynakça}

Akalın, Ş. H. (2011). Türkçe sözlük. “Alegori” Ankara: Türk Dil Kurumu. 88.

Aydemir, B. (2017). Sanatta Dirijizm devrimden telkine halkevleri inklap oyunlarl. İstanbul: Mitos Boyut.

Başkent Üniversitesi Özel Ayşeabla Okulları. (t.y.). Tarihçemiz. Erişim Adresi: http://ayseabla.k12.tr/kurumsal/ hakkimizda/tarihcemiz/

Behar, C. (2008). Musikiden müziğe Osmanll/Türk müziği: Gelenek ve modernlik. İstanbul: Yapı Kredi Yayınları. Cankaya, Ö. (2003). Bir kitle iletişim kurumunun tarihi: TRT 1927-2000. İstanbul: Yapı Kredi Yayınları.

Ertuğ, H. R. (1945). Radyo ve Öğretim, Radyo, 40, 1.

Gökalp, Z. (1968). Türkçülüğün esasları. İstanbul: Varlık Yayınevi. 
Hızır, N. (1942). Çocuk Saati Radyo Çocuk Kulübü. Radyo, 2, 30-31.

Hızır, N. (1943). Radyo Çocuk Kulübü, Radyo, 14, 12.

Hızır, N. (1944). Radyo Çocuk Kulübü Üç Yaşında. Radyo, 27, 11.

Kocabaşoğlu, U. (1980). Şirket telsizinden devlet radyosuna. Ankara: A. Ü. Siyasal Bilgiler Fakültesi Yayınlar1.

Kuruoğlu, H. (2006). Propaganda ve Özgürlük Aracı Olarak Radyo. Ankara: Nobel Yayın Dağıtım.

Kutluk, F. (1997). Müzik ve Politika. Ankara: Doruk Yayıncılık.

Kutluk, F. ve Aşkın, C. (2016). Fırat Kutluk Cihat Aşkın ile Konuşuyor. İllüzyon Cumhuriyet'in Klasik Müzik Serüveni (Der. Firat Kutluk). İstanbul: h2o Yayıncılık.

Kütükçü, T. (2012). Radyoculuk geleneğimiz ve Türk musikisi. Ankara: Ötüken Neşriyat.

Oransay, G. (1965). Batı tekniği ile yazan 60 Türk bağdar. Ankara: Küğ Yayını.

Radyo Anketimiz. (1948). Radyo, 78-79-80, 39.

Radyo Çocuk Kulübü ve Uzaklardaki Türk Çocukları. (1942). Radyo, 3, 22.

Radyo Okul Programlar1. (1949). Radyo, 85-86, 28-29.

Radyo Temsilleri. (1948). Radyo, 81-82, 21.

Radyomuzda Çocuk Kulübü. (1941). Radyo, 1, 18.

Radyomuzun Müzik Neşriyatı Tezgâhı Nasıl Çalışır?. (1942). Radyo, 2, 20-22.

Satır, Ö. C. ve Reyhan, H. (2018). Yürü Türk Oğlu: Bir Cumhuriyet İdeolojisi Olarak Türk Kimliğinin Inşasında Marşlar ve Çocuk Şarkıları. Cumhuriyetin Müzik Politikaları (Der. Fırat Kutluk). İstanbul: h2o Yayıncılık.

Say, A. (2005). Müzik ansiklopedisi. 3. Cilt. Ankara: Müzik Ansiklopedisi Yayınları.

Soykut, L. (1949). Müzik terbiyesi ve radyo. Radyo, 91-92-92, 1.

Tör, V. N. (1942). Radyonun büyüsü. Radyo, 4, 15

Wikipedia. (t.y.) Nedim Otyam. Erişim adresi: https://tr.wikipedia.org/wiki/Nedim_Otyam

Yazgan, T. (2015). Önce radyo vardı deneme yayılarl ve sonraki yıllar (1927-2014). Ankara: Erdem Basın Yayın Dağıtım.

Yıldırım, A., \& Şimşek, H. (2011). Sosyal bilimlerde nitel araştırma yöntemleri. Ankara: Seçkin Yayıncılık.

Yönetken, H. B. (1953). 25 çocuk şarkısı (radyo çocuk saatinde söylenen şarkılardan). İstanbul: Milli Eğitim Basımevi.

Yönetken, H. B. (1966). İlkokul müzik kılavuzu. İstanbul: Milli Eğitim Basımevi.

\section{Görsel Kaynakçası}

Görsel 1. Radyo Çocuk Kulübü. (1945). Radyo, Cilt 4, 38, 13.

Görsel 2. Aktüalite. (1943). Radyo, 21, 22.

Görsel 3. Ankara Radyosu Çocuk Saati Çalışmaları. (1954). İstanbul: Maarif Basımevi. 
Ek 1. Tek Sesli Orijinal Serbest Çocuk Şarkısı Örneği (Yönetken, 1953, s. 21).

16

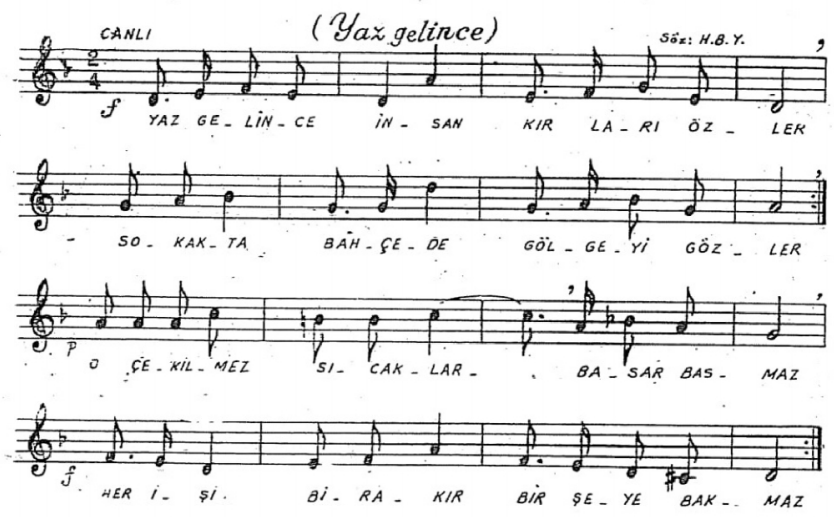

Yaz gelince insan kurları özler,

sokakta, bahçede gölgeyi gözler,

o çekilmez sicaklar basar basmaz

her işi bırakır, bir şeye bakmaz.

$$
\because
$$

Yaz gelince insan denizi özler

hep serin rüzgârı, meltemi gözler,

o güzelim denize dalar dalmaz,

her şeyi unutur, bir şeyi kalmaz.

Ek 2. Çok Sesli Orijinal Serbest Çocuk Şarkısı Örneği (Yönetken, 1953, s. 12).

12
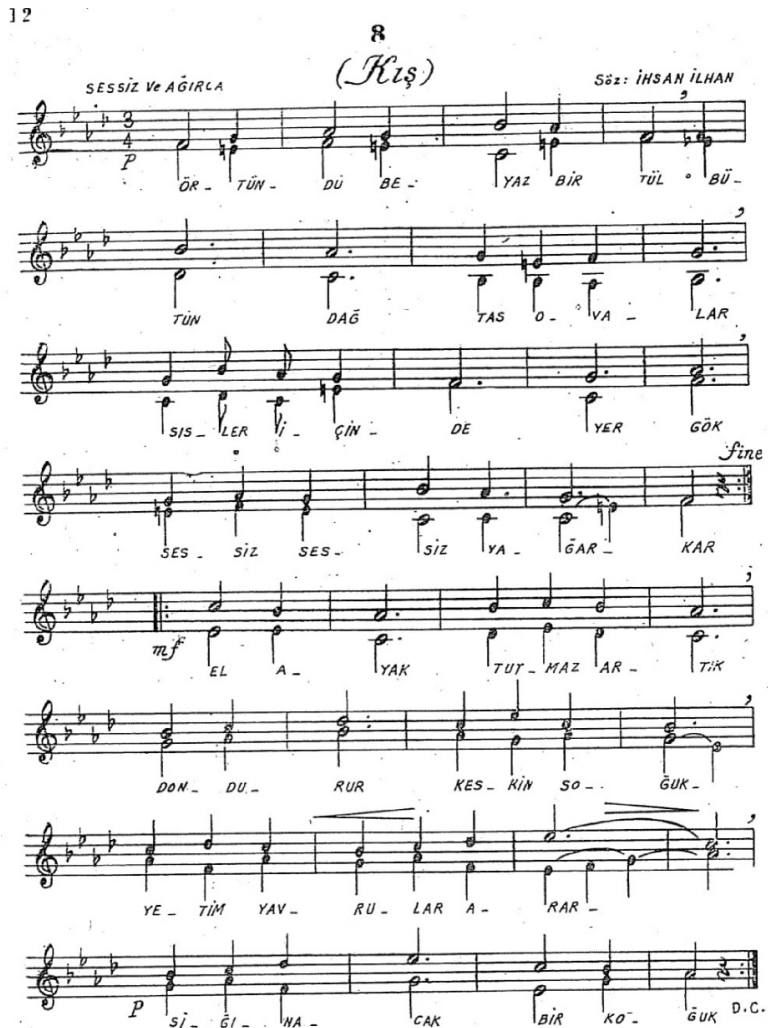

Örtïndii beyaz bir thi

bütün dağ, taş, ovalar,

sisler içinde yer, gök,

El ayak tutmaz artik, dondurur keskin soğk,

sessiz sessiz yağar kar.

yetim yavrular ara

sığınacak bir koğuk. 
Ek 3. Çok Sesli Marş Örneği (Yönetken, 1953, s. 14).

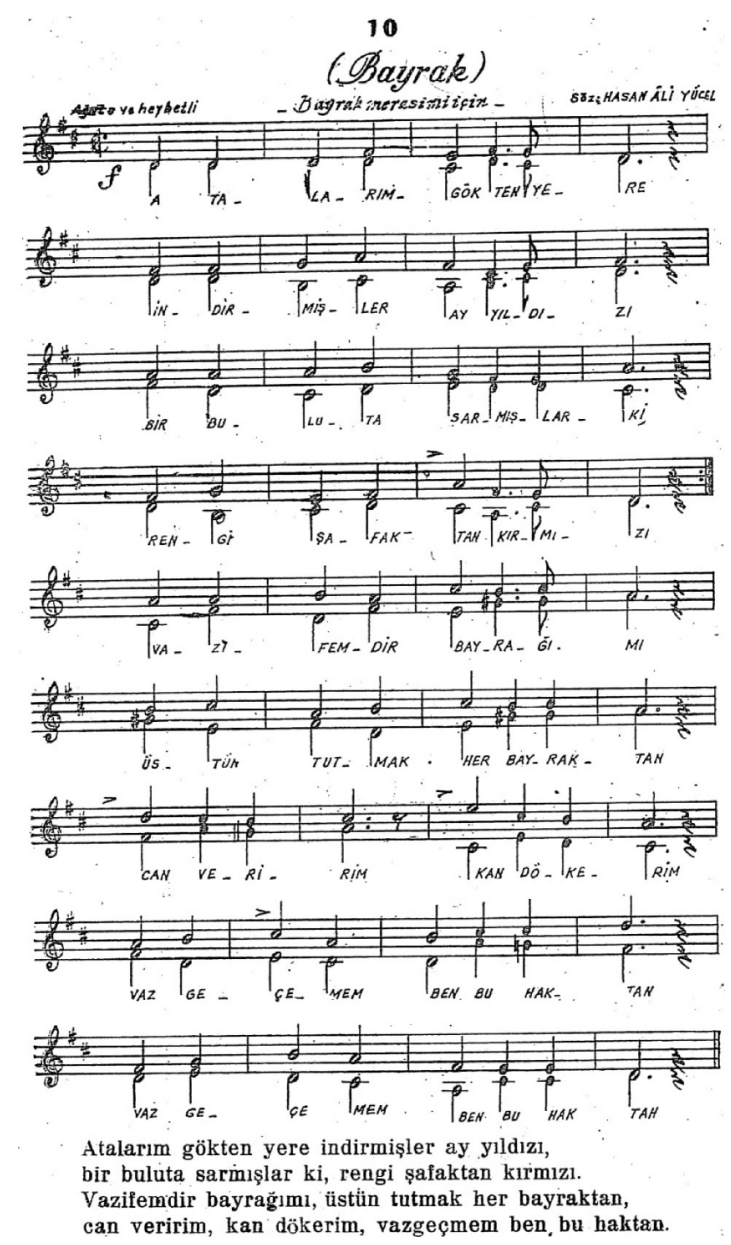

Ek 4. Çocuk ve Halk Ezgileri Üslubunda Bestelenmiş Çocuk Şarkısı Örneği (Yönetken, 1953, s. 23).

18

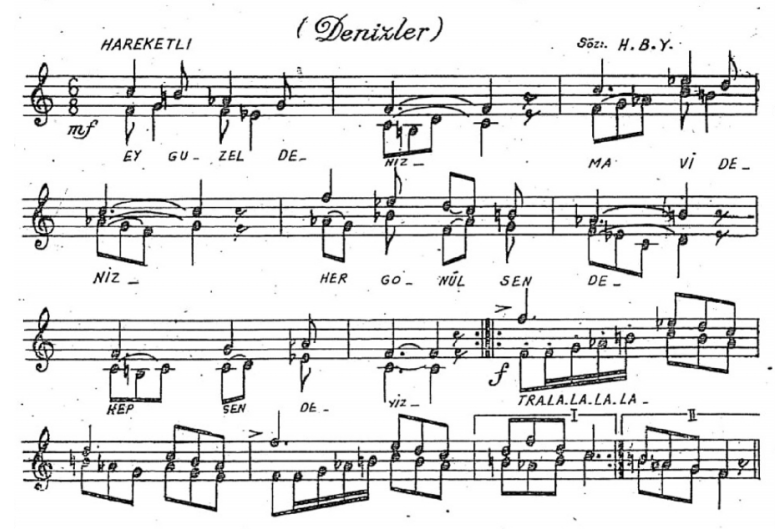

Ey güzel deniz, mavi deniz

her gönül sende, hep sendeyiz.

Tra lâ lâ lâ...

Ey güzel deniz, ey ak deniz,

çok zaman suyu berak deniz.

Tra lâ lâ lâ lâ..

Ey Karadeniz, taşkın deniz,

çok zaman çoşkun, aşkın deniz

Tra lâ lâ lâ lâ lâ... 
Ek 5. Halk Ezgilerinden Seçilmiş Çocuk Şarkısı Örneği (Yönetken, 1953, s. 27).

22

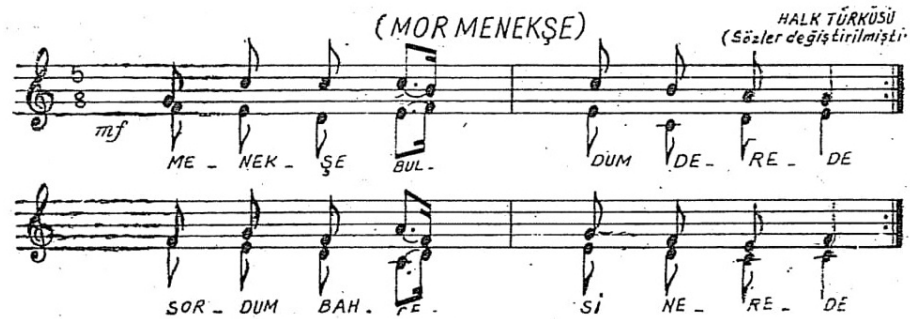

Menekșe buldum derede, sordum bahçesi nerede? menekşeler hep bir yerde, aman aman mor menekşe, aman canim mor menekșe, mis gibi kokan menekşe. 